RESEARCh PAPER

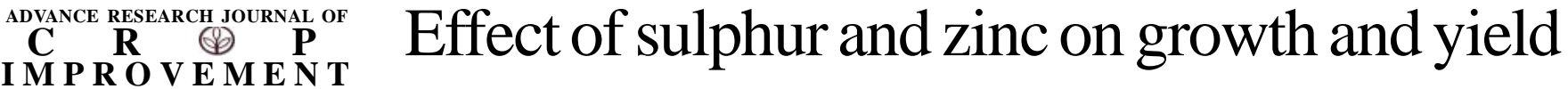 Volume $\mathbf{8}$ | Issue 2 | December, 2017 | 199-202 \\ $\bullet \bullet \bullet \quad$ e ISSN-2231-640X of mustard (Brassica juncea L.)
}

DOI :

10.15740/HAS/ARJCI/8.2/199-202

Visit us: www.researchjournal.co.in

\author{
HARISH CHANDRA SINGH AND GIRISH PANDEY ${ }^{1}$
}

\section{Authors' Info}

Associated Co-author : ${ }^{1}$ Department of Agronomy, ITM University, GWALIOR (M.P.) INDIA

Author for correspondence: HARISH CHANDRA SINGH Department of Agronomy, ITM University, GWALIOR (M.P.) INDIA

\begin{abstract}
A field experiment was conducted during 2014-15 with mustard (Brassica spp. L.) as a test crop under irrigated conditions on sandy clay loam soils with 4 levels of sulphur $(0,15$, 30 and $\left.45 \mathrm{~kg} \mathrm{ha}^{-1}\right)$ and 3 levels of zinc $\left(0,2.5\right.$ and $\left.5.0 \mathrm{~kg} \mathrm{ha}^{-1}\right)$ in Factorial Randomized Block Design with three replications. Seed and stover yield increased significantly upto $30 \mathrm{~kg} \mathrm{~S} \mathrm{ha}^{-1}$ and $5.0 \mathrm{~kg} \mathrm{Zn} \mathrm{ha}^{-1}$ application. Maximum seed yield (2011.7 $\mathrm{kg} \mathrm{ha}^{-1}$ ) observed with $\mathrm{S}_{3} \times \mathrm{Zn}_{2}$ which was significantly higher over rest all the treatment combinations except $\mathrm{S}_{3} \times \mathrm{Zn}_{2}$ and $\mathrm{S}_{2} \mathrm{x}$ $\mathrm{Zn}_{2}$ treatments. The maximum net return (Rs. 46475 and 45537$)$ was obtained from $\mathrm{S}_{3}(45 \mathrm{~kg} \mathrm{~S}$ ha1) $\mathrm{x} \mathrm{Zn} \mathrm{Zn}_{2}\left(5.0 \mathrm{~kg} \mathrm{Zn} \mathrm{ha}^{-1}\right)$ treatments and it was higher than all other treatments. Whereas, maximum B:C ratio (3.71) was obtained from $\mathrm{S}_{2}\left(30 \mathrm{~kg} \mathrm{~S} \mathrm{ha}^{-1}\right) \times \mathrm{Zn}_{2}\left(5.0 \mathrm{~kg} \mathrm{Zn} \mathrm{ha}^{-1}\right)$.

KEY WORDS : Growth, Effect, Mustard, Sulphur, Yield, Zinc

How to cite this paper : Singh, Harish Chandra and Pandey, Girish (2017). Effect of sulphur and zinc on growth and yield of mustard (Brassica juncea L.). Adv. Res. J. Crop Improv., 8 (2) : 199-202, DOI : 10.15740/HAS/ARJCI/8.2/199-202.

Paper History : Received : 08.10.2017; Revised : 12.11.2017; Accepted : 30.11 .2017
\end{abstract}

